\title{
New report of shallow water scleractinians from the Pliocene of Siena
}

\author{
Valeriano Spadini
}

Via A. Toti 4, 52046, Lucignano, Arezzo, Italy; email: spadiniv@inwind.it

\begin{abstract}
Three species of scleractinians belonging to the genera Hoplangia Gosse, 1860, Phyllangia Milne Edwards et Haime, 1848 and Thalamophyllia Duchassaing, 1870 are reported. For Hoplangia and Thalamophyllia this is the first report from the Mediterranean Pliocene. The three species were linked to hard or detrital bottoms of the infralittoral zone.
\end{abstract}

KEY WORDS Early Pliocene; Tuscany, Monte Calcinaio; Scleractinians; Caryophyllidae; Hoplangia, Phyllangia and Thalamophyllia.

Received 28.05.2020; accepted 12.08.2020; published online 06.11.2020

\section{INTRODUCTION}

Several contributions to knowledge of the scleractinian fauna of Siena, and in particular to the fauna of Monte Calcinaio in the Siena-Radicofani basin (Tuscany, Siena), were recently published (Spadini, $2015,2016,2018)$. A feature of this population is its quantitative and qualitative species richness, related to hard or detrital bottoms of the infralittoral to circalittoral and, in some cases, bathyal environments.

This note describes three species of the Monte Calcinaio, two belonging to the genera Hoplangia Gosse, 1860 and Thalamophyllia Duchassaing, 1870. They have no fossil representatives in the Mediterranean Pliocene and are currently represented by one species each in the Mediterranean Sea. The third species belongs to the genus Phyllangia Milne Edwards et Haime, 1848, which is represented by various species, living and fossil, one of which (P. mouchezii) occurs in the Mediterranean Sea. All these species are linked to hard or detrital bottoms, a type of habitat little known in the Mediterranean Pliocene, but present in that of Siena.

Monte Calcinaio (altitude $732 \mathrm{~m}$; 52 $54^{\circ} 55^{\prime} \mathrm{N}$, $11^{\circ} 48^{\prime} 59^{\prime \prime} \mathrm{E}$ ), where the materials were found, is near Radicofani in the Radicofani sub-basin (Tuscany, Italy). Marine sedimentation in this area started in the Zanclean with deposition of deep-sea clays over continental Miocene sediments (Bonini \& Sani, 2002). The microfaunal association in the Radicofani Basin has been attributed to the Globorotalia margaritae/puncticulata Biozone of the Early Pliocene (Zanclean) (Bossio et al., 1992; Pascucci et al., 2006). For other general characteristics of this site, see Spadini $(2015,2016,2018)$.

\section{RESULTS}

Systematics

Classis ANTHOZOA Ehrenberg, 1834

Subclassis HEXACORALLIA Haeckel, 1866

Ordo SCLERACTINIA Bourne, 1900

Familia CARIOPHYLLIIDAE Dana, 1846

Genus Hoplangia Gosse, 1860

TYPE SPECIES. Hoplangia durotrix Gosse, 1860, by monotypy. 
Remarks. Hoplangia Gosse, 1860 is only represented by the extant $H$. durotrix Gosse, 1858 that lives in the Eastern Atlantic and the Mediterranean Sea. Cairns (1995) reported this species from New Zealand. For its general characters, see Joubin (1927), as Microcyathus neapolitanus Doderlein, 1903, and Zibrowius (1980).

Hoplangia durotrix is linked to rigid substrates, common in coastal areas and coralligenous zones to depths of about $150 \mathrm{~m}$ (Zibrowius, 1980).

\section{Hoplangia sp. (Fig. 1)}

EXAmined MATERIAL. Monte Calcinaio: one colony.

DESCRIPTION. Fragment of colonial corallum, bushy, very small in size (17.6 x 8.4 x $11.6 \mathrm{~mm})$ formed by extratentacular budding. The corallites originate from the sides of other corallites. Theca covered with coarse granules, wide costae, not always well defined.

Small, circular or slightly elliptical calices (max. 3.2 x $4.7 \mathrm{~mm}$ ). Septa 24-36 arranged hexamerally in four incomplete cycles. Fossa very deep. $\mathrm{S}_{1}$ more robust and thicker than $\mathrm{S}_{2}, \mathrm{~S}_{3}$ converging with $\mathrm{S}_{2}$ deep in fossa; $\mathrm{S}_{4}$ small, only present in some of the six systems. Axial edges of septa smooth, but the edges of $S_{1}$ and $S_{2}$ are slightly wavy in the centre, tuberculated and probably fused together at their base. Lateral faces of septa bear very thick circular granuli. Pali and columella absent.

REMARKS. Due to the general characters, the colony (inner edge of septa smooth and nontoothed, absence of pali and columella) it can be included in the Caryophylliidae family. In addition to the lack of pali and columella, the Siena colony shares the following characters with Hoplangia: the large granules of the theca, the costae not well defined, the septal characters with $\mathrm{S}_{1}>\mathrm{S}_{2}$, the tubercles of the axial margin of the septa fused at the bottom of the calice, and the large granules on the lateral faces of the septa.

Genus Phyllangia Milne Edwards et Haime, 1848

TyPe SPECIES. Phyllangia americana Milne Edwards \& Haime, 1849, by subsequent designation (Milne Edwards \& Haime, 1850).

REMARKS. The genus Phyllangia was included in the Rhizangidae family, but was recently transferred to the Caryophylliidae by Zibrowius (1980).

The oldest fossils of the genus Phyllangia date back to the Oligocene of Albania (Lorenthey, 1926).

Other species have been described for the Miocene of Western Europe (Milne Edwards \& Haime, 1848-1850; Michelotti, 1871; Chevalier, 1961), Borneo (Gerth, 1923), Florida (Wells, 1947; Gane, 1900) and Land of Fires (Squires, 1963).

Various species can be found along the Atlantic and Indo-Pacific coasts (Cairns \& al., 1999). One of these, Phyllangia mouchezii (Lacaze-Duthiers, 1897), present in the Atlantic Ocean and in the Mediterranean Sea (Zibrowius, 1980), is considered a subspecies of $P$. americana Milne Edwards \& Haime, 1848 (Chevalier, 1966; Cairns, 2000).

\section{Phyllangia sp. (Fig. 2)}

EXAMINED MATERIAL. Monte Calcinaio: one colony.

DesCription. Colonial corallum composed of two complete and two incomplete corallites. Corallites arising by extratentacular budding from a thick crusty coenosteum or from the lower theca of a parent corallite. Corallites cylindrical, 5-6 $\mathrm{mm}$ tall, closely spaced or fused at their base. Theca granular and costate at the main septa. Shallow fossa, circular or slightly elliptical calice ( $\max 12.6$ x $9.7 \mathrm{~mm}$ ). Septa in five incomplete cycles arranged hexamerally, but incomplete and poorly conserved. The largest calice has 52 septa, but is not fully preserved.

$S_{1}$ and $S_{2}$ equal or sub equal, thicker than the septa of higher cycles, $\mathrm{S}_{3}$ dilated at their base, forming an indistinct paliform lobe, present only in some septa. Some $\mathrm{S}_{4}$ seem to have slightly serrated margins, $S_{5}$ reduced and not very evident, present in the largest corallite. $\mathrm{S}_{1}, \mathrm{~S}_{2}$ and $\mathrm{S}_{3}$ merge at bottom of calice, while $\mathrm{S}_{4}$ and $\mathrm{S}_{5}$ are free. Lateral face of septa with sharp granules. Columella papillary, very small, composed of few elements. Endothecal dissepiments present.

REMARKS. Among the species described, this colony resembles Phyllangia blakey Wells, 1947 from the Upper Miocene of Florida, and Phyllangia mouchezii, currently living in the Mediterranean Sea (see Zibrowius, 1980).

De Angelis (1894) described Phyllangia mi- 
crosyderea, a species with completely different morphological characters from the Pliocene of Albugnano (Asti).

\section{Genus Thalamophyllia Duchassaing, 1870}

TYPE SPECIES. Desmohyllum riisei Duchassaing, 1860 , by monotypy.

DiAgNosis. Colonial corallum formed by extratentacular budding of ceratoid corallites from a thin common basal coenosteum resulting in reptoid to phaceloid coralla. Pali and columella absent; fossa deep. Endotheca absent (Cairns, 1995).

REMARKS. Thalamophyllia is a genus of colonial coral characterized by reptoid colonies, but isolated corallites have often been found (Cairns, 1995).
Four species are recognised: T. riisei (Duchassaing et Michelotti, 1864) of the western Atlantic, T. tenuescens (Gardiner, 1899) of the Indian Ocean and western and central Pacific, T. gasti (Doderlein, 1913) of the Mediterranean Sea and eastern Atlantic, and T. gombergi Cairns, 1979 of the western Atlantic (Cairns et al., 1999).

\section{Thalamophyllia sp. (Fig. 3)}

EXAMINED MATERIAL. Monte Calcinaio: one specimen.

DESCRIPTION. Corallum conical, elongated, 11.7 $\mathrm{mm}$ tall, with a calicular diameter of $2.2 \mathrm{~mm}$, curved distally. Broad base, covered with evident granuli. The six costae corresponding to the septa

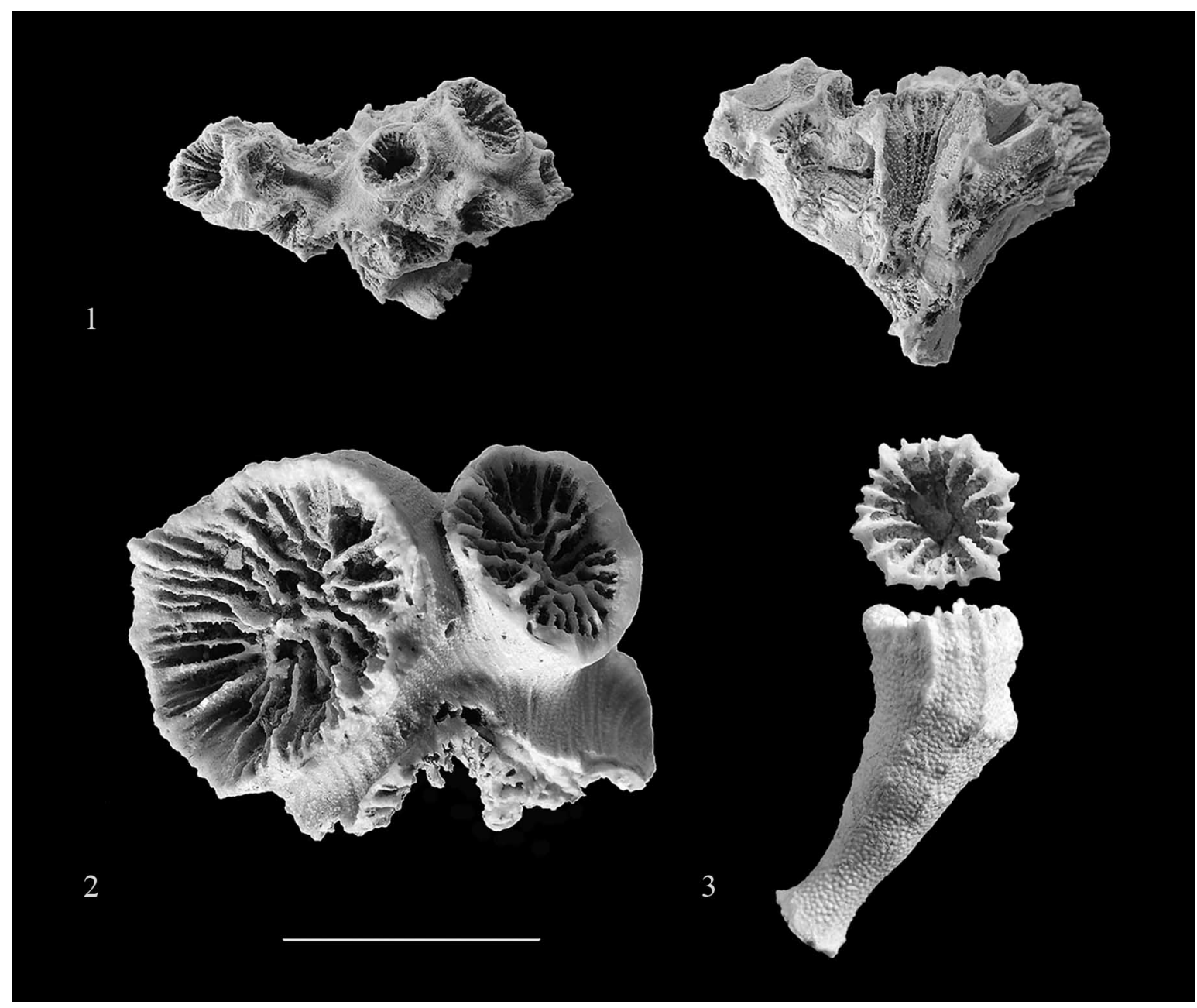

Figures 1-3. Scleractinian of Early Pliocene (Zanclean) of Monte Calcinaio. Fig. 1: Hoplangia sp. Fig. 2: Phyllangia sp. Fig. 3: Thalamophyllia sp. $($ Scale bar $=1 \mathrm{~cm})$ 
of the first cycle are evident from the peduncle. The costae corresponding to the second and third cycle are faintly evident. Calice regularly circular. A total of 20 septa arranged in six systems and three incomplete cycles, with four $\mathrm{S}_{3}$ missing in two opposing systems.

$S_{1}$ robust, reaching half of the calicinal radius, $S_{2}$ is thinner, shorter than $\mathrm{S}_{1}$, and $\mathrm{S}_{3}$ is even smaller than the previous cycle. Very deep fossa, no columella.

REMARKS. According to the data reported in $\mathrm{Zi}$ browius (1980) and Addamo et al. (2016), young Desmophyllum of equal calicinal diameter have more septa than Thalamophyllia. From a morphological point of view, the specimen from Monte Calcinaio is similar to Desmophyllum fasciculatum (= T. gasti) in Joubin (1927) and Thalamophyllia tenuescens (Gardiner, 1899) from New Zealand and the Philippines (Cairns, 1995).

Other small-sized specimens have been found on Monte Calcinaio, but they are generally in a very poor state of conservation. All these specimens are characterized by a broad base, three incomplete cycles of septa, theca with granules and costae variously developed.

\section{CONCLUSIONS}

The genera Hoplangia and Thalamophyllia, hitherto known only from the Pleistocene and still living in the Mediterranean Sea, are two new genera from the Mediterranean Pliocene. By contrast, the genus Phyllangia is reported since the Miocene, but its presence in the Pliocene was uncertain (Vertino et al., 2014).

The species described show a certain morphological affinity with the corresponding species extant in the Mediterranean and it is therefore likely that they had similar ecological needs (Zibrowius, 1980).

Thalamophyllia has a wide bathymetric range between 25 and $2460 \mathrm{~m}$ (Cairns, 2000). T. gasti currently lives in the Mediterranean Sea at shallow depths in caves, under small overhangs and in coralligenous environments with Corallium rubrum. Hoplangia lives between depths of 6 and $150 \mathrm{~m}$ (Zibrowius, 1980), while live specimens of Phyllangia mouchezii have been found between depths of 1 and $55 \mathrm{~m}$ (Zibrowius, 1980), although other species reach greater depths. It is therefore possible to hypothesize that the specimens found on Monte
Calcinaio lived at depths between 6 and 55 meters, corresponding to the infralittoral zone.

This bathymetric range matches that of other species typical of hard or detrital bottoms, from Monte Calcinaio, such as Madracis almerai, Monomyces sp., Cladopsammia sp., sharing the same habitats and is confirmed by various species of gastropods (Gibbula sp., Persististrombus coronatus, Thais hörnesiana) and bivalves (Glycymeris bimaculata, Aequipecten scabrellus, Ostrea sp., Gigantopecten latissimus, Spondylus crassicosta) which are found especially in the easternmost part of Monte Calcinaio.

The finding of these three species related to hard bottoms confirms the importance of this site for the study of the scleractinian fauna of the Pliocene of Siena and of the Mediterranean area in general.

\section{ACKNOWLEDGEMENTS}

I thank Helen Ampt (Siena, Italy) for revising the English.

\section{REFERENCES}

Addamo A.M., Vertino A., Stolarski J., García-Jiménez R., Taviani M. \& A. Machordom, 2016. Merging scleractinian genera: the overwhelming genetic similarity between solitary Desmophyllum and colonial Lophelia. BMC Evolutionary Biology, 16: 108. https: //doi.org/10.1186/s12862-016-0654-8

Bossio A., Cerri R., Costantini A., Gandin A., Lazzarotto A., Magi M., Mazzanti R., Mazzei R., Sagri M., Salvatorini G. \& Sandrelli F. (1992). I bacini distensivi neogenici e quaternari della Toscana. In: Guida alle escursioni post-congresso (Società Geologica Italiana, $76^{\circ}$ Riunione estiva "L'Appennino Settentrionale" and Società Italiana di Mineralogia e Petrologia, Convegno "Minerogenesi appenninica", Firenze 21-23 settembre 1992): 199-277.

Cairns S.D., 2000. A revision of the shallow-water azooxanthellate Scleractinia of the western Atlantic. Studies on the Natural History of the Caribbean Region, 75: 1-231.

Cairns S.D., Hoeksema B.W. \& van der Land J., 1999. Appendix: List of Extant Stony Corals. Atoll Research Bulletin, 459: 13-46.

Cairns S.D., 1995. The marine fauna of New Zealand: Scleractinia (Cnidaria: Anthozoa). New Zealand Oceanographic Institute memoir, 140 pp. 
Chevalier J.P., 1961. Recherces sur les Madréporaries et les formations récifales mocénes de la Méditerranée occidentale. Mémoires de la Société de France. 40, 562 pp. 26 tav.

Chevalier M., 1966. Contribution à l'étude des Madréporaries des côtes occidentales de l'Afrique tropicale. Bulletin de 1'Institut fondamental d'Afrique noire, 28: 912-975; 1356-1405.

De Angelis G., 1894. I Corallarj dei terreni terziari dell'Italia settentrionale. Collezione Michelotti, Museo geologico della R. Universita di Roma. Atti della Regia Accademia dei Lincei, Memorie della Classe di Scienze Fisiche, Matematiche e Naturali 5: 164-280.

Gane H.S., 1900. Some Neocene corals of the Unites States. Proceedings of the Unites States National Museum, 22: 179-203.

Gerth H., 1923. Die Anthozoenfauna des Junggtertiärs von Borneo. Sammlungen des Geologischen ReichsMuseum in Leiden, 10: 37-136.

Joubin L., 1927. Microcyathus neapolitanus. Faune et flore de la Mediterranée. Fiche.

Michelotti G., 1871. Materiaux pour servir a la paléontologie du terrain tertiaire du Piémont. Memorie della Regia Accademia delle Scienze di Torino, 25: 257361.

Milne Edwards H. \& Haime J., 1848-1850. Recherches sur les Polypiers. Annales des Sciences Naturelles, series 3: Turbinolidae, t. 9, pagg. 221-344, tavv. 710; Eupsammidae t. 10, pagg. 65-114, tav. 1; Astreidae t. 10, pagg. 209-320, tavv. 5-9; t. 11, pagg. 235-312; t. 12 pagg. 95-197; Oculinidae t. 13, pagg. 63-110, tavv. 3-4; Fongidae t. 15, pagg. 73-144.
Pascucci V., Costantini A., Martini I.P. \& Dringoli R., 2006. Tectono-sedimentary analysis of a complex, extensional, Neogene basin formed on thrust-faulted, Northern Apennines hinterland: Radicofani Basin, Italy. Sedimentary Geology, 183: 71-97.

Spadini V., 2015. Sclerattiniari del Pliocene senese (Cnidaria, Anthozoa). Accademia delle Scienze di Siena detta dei Fisiocratici, Memorie, 13: 1-159.

Spadini V., 2016. First occurrence of the genus Bathelia (Anthozoa, Scleractinia) from the Mediterranean Pliocene. Bollettino della Società Paleontologica Italiana, 55: 219-222.

Spadini V., 2018. The genus Crispatotrochus TenisonWoods, 1878 (Anthozoa Scleractinia) from the Mediterranean Pliocene. Biodiversity Journal, 9: 345350. https://doi.org/10.31396/Biodiv.Jour.2018.9.4. 345.350

Squires D.F., 1963. Madreporas Rizángidas fósiles y vivente de la Argentina. Neotropica, 9, 28: 9-16, 11 figg.

Vertino A., Stolarski J., Bosellini F.R. \& Taviani M., 2014. Mediterranean Corals Through Time: From Miocene to Present. In: S. Goffredo \& Z. Dubinsky (Eds.), The Mediterranean Sea: Its history and present challenges, pp. 257-274.

Wells J.W., 1947. Coral studies. Part IV. A new species of Phyllangia from the Florida Miocene. Bullettin of American Paleontology, 53: 163-176.

Zibrowius H., 1980. Les Scléractiniaires de la Méditerranée et de l'Atlantique nord-oriental. Memoires de l'Institut Océanographique, Monaco, 11: 284 pp. 
